\title{
Imperatriz: de Vila à Cidade Comercial e Ponto de Apoio no Desenvolvimento Amazônico
}

\section{Imperatriz: from Town to Commercial City and Logistical Base for Amazonian Development}

\author{
Cláudia Romaneli Nogueira ${ }^{i}$ \\ Secretaria Estadual de Educação do Rio de Janeiro \\ Rio de Janeiro, Brasil
}

\begin{abstract}
Resumo: Através da história econômica da cidade de Imperatriz no Estado do Maranhão, visa-se detectar a existência de atividades relacionadas a surtos econômicos, dinâmica demográficae criação de "trabalho novo". Inicialmente, contextualiza-se o Estado do Maranhão no período da economia colonial, aprofundando-se as origens do povoado de Imperatriz até sua elevação à cidade, tendo-se por base as atividades que sustentaram sua vida econômica. O verdadeiro boom demográfico de Imperatriz ocorreu com a construção da rodovia Belém-Brasília, consolidando as atividades comerciais da cidade. Em seguida, Imperatriz especializou-se em serviços atuando como polo de comércio da região Tocantina.
\end{abstract}

Palavras-chaves: Amazônia, Imperatriz, surtos econômicos.

\begin{abstract}
The economic history of Imperatriz, Maranhão, is analyzed in order to detect the rise of new activities related to economic surges, changing demographics and the creation of a new division of labour. First, the origin of Imperatriz is contextualized in the colonial history of Maranhão state and then its growth into an important city is traced focusing on its changing economic base. Then, the demographic boom provoked by the construction of the Belém-Brasília highway is shown to have consolidated the commercial activities of the city. Finally, the role of Imperatriz today as a provider of advanced services and commerce for the Tocantina region is treated.
\end{abstract}

Keywords: Amazon, Imperatriz, economic surges.

\section{Introdução}

A cidade de Imperatriz não tem seu grande surto vinculado ao ciclo da borracha. Localizada no sudoeste maranhense, sua história recente não se limita à trajetória do estado a que pertence - seu maior surto de crescimento econômico associa-se à construção da rodovia Belém-Brasília em 1958, que valorizou sobremaneira sua posição estratégica. Está inserida na porção maranhense amazônica, em uma área de contato entre a floresta amazônica e o cerrado nordestino, e compõe também um importante triângulo urbano, cujos vértices incluem as cidades de Marabá (Pará) e Araguaína (Goiás). Como todas as cidades amazônicas, sua trajetória histórica inicial está ligada à posição junto aos rios.

\footnotetext{
i Professora da Secretaria Estadual de Educação e da Secretaria Municipal de Educação do Rio de Janeiro.romanelibr@yahoo.com.br
} 
Nogueira, C. R.

As incursões fluviais rio acima, partindo tanto de Belém como de São Luís no sentindo de Goiás, originaram os meios e a decisão geopolítica de fundação do núcleo em meados do século XIX. Somente a partir de então o sul maranhense se sobressai no cenário regional como a última fronteira nordestina e como área de ligação entre os estados do Pará e Goiás, graças aos diversos povoamentos nas margens dos rios, especialmente do rio Tocantins.

Dentre esses povoamentos destaca-se a Vila de Imperatriz, que, fundada à margem direita do rio Tocantins, antes de sua confluência com o rio Araguaia, passou a agregar um território de mais de 50 mil quilômetros quadrados, influindo em uma área que hoje abrange quase vinte municípios, comumente denominada de sudoeste maranhense e região Tocantina. Entre denominações locais e regionalizações propostas, o IBGE oficialmente considera o município de Imperatriz (atual e sua antiga configuração) como mesorregião do Oeste Maranhense e microrregião de Imperatriz, e o governo do estadoa identifica como Região de Planejamento do Tocantins.

Há tempos, toda a área do sul do estado - sertões, na concepção de áreas ainda não ocupadas por atividades diretas ou indiretas dos colonizadores - era cobiçada pela abundância de terras para a atividade rural e pastoril. Essa área foi palco de redução contínua dos povos indígenas que viviam às margens dos rios e de intenso fluxo migratório de nordestinos, que também se utilizavam das vias de comunicação fluvial, já que as primeiras estradas só foram concebidas a partir de 1860 e em direção a Belém e São Luís (FRANKLIN, 2008). Até o início do século XX, a região sul do Maranhão, inclusive o município de Imperatriz, era considerada sertão.

Atividades econômicas relacionadas ao abastecimento de carne e couro, à economia da borracha e da castanha, do arroz e da madeira e à corrida pelo ouro, além da agricultura de subsistência, delinearam a região de Imperatriz, ora dinamizando-a, ora deixando-a em completo isolamento, como será analisado neste trabalho.

Desde a condição de vila até sua elevação a cidade em 1924, Imperatriz passa por décadas de estagnação e curtos momentos de euforia, tendo na construção da Belém-Brasília a âncora de desenvolvimento econômico e forte crescimento demográfico. A década de 1950, até 1960, marca a etapa inicial do surto econômico e de novas atividades na cidade, que representa a ponta de lança em direção à "fronteira agropecuária", e, mais ainda, a afirmação do rodoviarismo como opção de integração nacional e motor de desenvolvimento.

Imperatriz se consolida como cidade comercial, atuando no atacado e varejo e na oferta de serviços especializados nas áreas de educação e saúde. A partir da década de 1980, é possível afirmar que a cidade se consolida também como principal centro urbano no contexto regional, ou seja, no âmbito de sua região de influência denominada extraoficialmente de região Tocantina ${ }^{1}$, que não tem limites muito precisos.

Nesse contexto, a cidade de Imperatriz, estando vinculada ao sudoeste do Maranhão, ao norte do Tocantins e ao sudeste do Pará, assume posição estratégica regional, especialmente no setor terciário da economia. Divide atualmente com Marabá e Araguaína a influência regional.

Através da história econômica, visa-se detectar a existência de atividades que estabeleçam surtos econômicos e sua relação ou não com o crescimento demográfico, e ainda se os surtos estão ou não associados à inserção de trabalho novo na cidade. 
A primeira parte destetrabalho contextualiza o estado do Maranhão no período da economia colonial, contexto bem diverso dos atuais estados amazônicos em suas atividades econômicas e estratégias políticas até a fundação do povoado de Imperatriz. A segunda parte aprofunda-se nas origens do povoado até sua elevação a cidade e as atividades que sustentaram sua vida urbana. A etapa seguinte relata o verdadeiro boom demográfico de Imperatriz com a construção da rodovia Belém-Brasília, consolidando as atividades comerciais da cidade, e, finalmente, a última parte analisa a especialização em serviços e sua consolidação como polo de comércio da Região Tocantina.

\section{Contexto Histórico-geográfico da Borda Amazônica Oriental: o Estado do Maranhão}

As terras americanas sob domínio lusitano foram negligenciadas por décadas posteriores ao descobrimento, até que interesses de posse da terra e exploração das riquezas naturais (as drogas do sertão e a mão de obra indígena) impulsionaram a coroa a empreender a conquista.

Inúmeras estratégias de divisão político-administrativas foram empreendidas no Brasil setentrional, nos séculos XVII e XVIII, para incrementar e garantir a integridade das suas terras. $\mathrm{O}$ estado maranhense e suas capitanias tiveram papel importante na história e na configuração territorial do país por sua posição geográfica, no entanto, permaneceram por longo período com terras em demasia e pouco produtivas (STUART FILHO, 1959).

O Maranhão foi o limite norte do modo colonial de ocupação do Nordeste, baseado na produção de açúcar nas matas e criação de gado nos campos, e foi ponta de lança para a ocupação da Floresta Amazônica mediante a caça aos índios e a extração das drogas do sertão.

Devido à sua condição de contato entre a floresta e o cerrado, dois gêneros de vida se estabeleceram no estado, à semelhança do que ocorria na faixa costeira do Brasil - o litoral florestado, onde se concentravam a população e as atividades, e o sertão, correspondente às grandes extensões do cerrado pouco habitadas pelos colonizadores, domínio do trânsito e da criação de gado à medida que se expulsavam os índios.

\section{O litoral}

Em 1620 e 1621, no período da União Ibérica, dividiram-se as capitanias do Brasil em duas: estado do Maranhão, que abrangia a capitania do Maranhão, Pará e Ceará, com capital em São Luís, e o estado do Brasil, que abrangia as outras capitanias, com capital em Salvador. À mesma época, chegavam à capitania do estado do Maranhão 240 casais de açoreanos que dariam início à indústria do açúcar, cujo primeiro engenho foi instalado no Itapecuru (cidade próxima de São Luís), e às lavouras de mandioca, algodão e tabaco, cuja produção era, no entanto, rudimentar e atendia às necessidades básicas (MEIRELES, 1960).

Após intenso processo de anexação e desmembramento politico-territorial, em 1753, o estado do Maranhão passou a se chamar estado do Grão-Pará e Maranhão, tendo a sua capital sido transferida da cidade de São Luís para Belém do Pará. Em seguida, 
Nogueira, C. R.

em 1772, a Coroa Portuguesa divide oestado do Grão-Pará e Maranhãoem duas unidades administrativas: oestado do Grão-Pará e do Rio Negro, com sede em Belém do Pará, e oestado do Maranhão e Piauí, com sede em São Luís. Mais tarde, em 1811, volta a ser o estado do Maranhão aproximadamente como em 1620. Essas ações estão ligadas às estratégias do governo português de assegurar o território e suas riquezas, necessitando assim de maior organização política e econômica interna.

Segundo Stuart Filho (1959 p. 313), o povoamento permaneceu "... largo tempo adstrito a pontos dispersos, formadores de verdadeiros nódulos demográficos de pouco vulto e importância, disseminados em enormes áreas territoriais desertas ou dominadas apenas por escassa população indígena, que envolveriam com grande lentidão". No início do século XVII, estimavam-se em 250 os moradores livres para a cidade de São Luís e arredores, mais importante econômica e socialmente do que a cidade de Belém, com oitenta moradores livres apenas. Sobretudo de São Luís, e também de Belém, partiam as expedições de caça ao índio e controle do território amazônico.

A proibição da fabricação de produtos e do comércio livre, a extrema pobreza interna, dados a falta de gêneros de primeira necessidade e os parcos investimentos nas atividades desenvolvidas, a dificuldade de circulação em paisagens tão hostis e sem meios eficientes de comunicação, a pouca honestidade da política local e de outras autoridades sociais são alguns dos motivos do fraquíssimo desenvolvimento econômico e demográfico de todo o estado do Maranhão durante o longo período da economia colonial.

Cumpre outra consideração, que é a natureza da força de trabalho. As atividades extrativistas e agrícolas desenvolvidas no Maranhão usavam prioritariamente o índio, considerado a única mão de obra disponível pelos colonos, e estes constantemente clamavam às autoridades a situação de penúria por motivo de falta de braços para a lavoura. Em Meireles (2008) é apontada a posição do padre Antônio Vieira, da Companhia de Jesus, no Maranhão sobre a questão:

[...] a miséria dos povos, não era pela falta de cativos, que ultimamente haviam entrado na capitania, entre forros e escravos, cerca de 5 mil silvícolas, mas pela dificuldade de transporte, a carência de mantimentos, a deficiência de administração, de operários e artífices, e, principalmente, pela vaidade e luxo dos colonos que não mediam os gastos de suas posses, a par, tudo isso, da carestia de vida decorrente da situação que atravessava a própria metrópole, na Europa. (Carta de Padre Antônio Vieira em 12 de fevereiro de 1661)

Não diferente do restante do país, a ideia de enriquecimento rápido e fácil era amplamente difundida, e na região do Maranhão levou a campos relativamente opostos: os colonos, com uma cobiça desmedida, e os jesuítas, que acolhiam os índios contra a escravização e a dizimação. Posição muito ambígua, uma vez que os colonos, por meio de resgates, reduções, sucessivas e constantes entradas, não mediam esforços na mercadoria servil, cujos missionários participavam com direito a uma parte.

Sem dúvida, as divergências entre colonos e missionários (na questão da escravização indígena), o choque de autoridades lusitanas, a pequena entrada de imigrantes, as baixas decorrentes da insistente varíola e a matança produzida pelos nativos justificam ainda o fraco desenvolvimento da região (MEIRELES, 1960). 
Os dados demográficos não são abundantes, mas para toda a capitania do Maranhão os relatos demonstram cerca de 78 mil habitantes no final do século XVIII, com 46,5\% da população africana. Crescimento, sem dúvida, decorrente da entrada de escravos, já anteriormente sugerida pelas autoridades para suprir a carência de mão de obra. E já como província, no início do XIX, a população é estimada em 152 mil habitantes (Tabela 1), sendo a de São Luís de 19.611 habitantes, distribuídos em 2.714 casas (idem, 2008).

Tabela 1 - População - Capitania do Maranhão

\begin{tabular}{c|c}
\hline Ano & População \\
\hline 1798 & 78.860 \\
1802 & 100.000 \\
\hline 1822 & 152.893 \\
\hline
\end{tabular}

Fonte: Meireles, 2008.

No que diz respeito aos aspectos econômicos, a famosa Companhia Geral de Comércio do Grão-Pará e Maranhão, constituída em São Luís em 1752, teve importante papel, pois objetivava explorar o comércio da importação de escravos negros, introduzindo-os nas capitanias, e animar-lhes o comércio fomentando a agricultura. Dinamizou-se a economia no governo do Marquês de Pombal, associada também à sua política no plano interno. Em meados do século XVIII, das 8 freguesias existentes, 5 engenhos de açúcar e 203 fazendas de criação de gado, as freguesias de Pastos Bons e Aldeias Altas concentravam cerca de $40 \%$ das fazendas de gado da capitania do Maranhão (ABREU, apud MEIRELES, 2008).

As principais atividades no Maranhão estavam ligadas à produção de algodão, arroz, tabaco e açúcar, além de produtos secundários, como a mandioca, para a fabricação de aguardente e para a farinha, o cravo, a salsaparrilha, o âmbar, o cacau, a canela, o anil, o urucu, ibirapitinga, sal e a criação de gado. Apenas o cacau e a baunilha (mais tarde o cravo) se haviam salientado como produtos exóticos exportáveis, o que exigia apenas um único navio por ano, com todos os produtos exportáveis, zarpando de São Luís para a metrópole portuguesa.

O volume de exportação cresceu e se diversificou. De 1760 a 1771, Meireles (2008) aponta 71 navios, conduzindo 112.339 arrobas de algodão, 4.437 de arroz, 21.084 de gengibre, 398 de cacau, 249.780 de atanados (couros curtidos), 255 alqueires de tapioca, além de outros produtos, como copaíba, cravo, anil, café, seda em rama, âmbar, tartaruga etc. Verifica-se, assim, o quanto foi intensa a ação da Companhia até ser extinta em 1778.

A base da atividade algodoeira e rizícola respondiam a uma demanda externa mais intensa, mais contínua e mais longa do que os estímulos de atividade agrícola na região amazônica. Segundo Santos (1980), a província do Maranhão se beneficiou do processo de revolução industrial inglesa e da crise dos fornecimentos americanos à Europa, ocasionada pela Guerra da Independência dos Estados Unidos. 
Nogueira, C. R.

A exportação de couro estava ligada à criação de gado, que se expandia por todo o sertão decorrente das frentes exploratórias em áreas com ampla oferta de terras. Eram mais de quatrocentas fazendas de gado vacum e cavalar em todo o estado, distribuídas por diversas freguesias, como Pastos Bons, localizadas ao sul do estado. Pelos sertões também passavam pequena parte da produção de algodão (pano grosso de algodão) para Minas Gerais e Goiás, sempre de forma muito precária devido à dificílima comunicação com o restante do Brasil.

O panorama socioeconômico do Maranhão no final do período colonial era extremamente favorável, especialmente pela ação da Companhia de Comércio, que implementou com relativo sucesso as lavouras do algodão e arroz, fomentou a importação de grande contingente de mão de obra africana e fez o Maranhão conhecer uma excepcional prosperidade. Há, assim, condições de entender as origens do povoado de Imperatriz como um ponto estratégico nos caminhos trilhados no sertão.

\section{As frentes exploratórias no sertão - importância do rio Tocantins}

O Maranhão foi povoado e explorado desde o século XVI nos moldes coloniais, onde os esforços econômicos e de povoamento se concentravam no litoral para cumprir o papel de colônia junto às metrópoles europeias. A capitania maranhense, no início do século XVII, foi alvo de disputas estrangeiras, francesa, holandesa e espanhola, até que prevaleceu o domínio português e o contínuo descaso com as regiões não litorâneas, chamadas genericamente de "sertão".

Segundo Monteiro (2001), o contexto colonial introduziu a oposição entre povoado e não povoado, ou seja, entre litoral e sertão, como uma referência espacial e também de ordem social, entre universos distintos. A analogia também cabe ao binômio tupi-tapuias, que designava uma classificação simplista da diversidade dos grupos indígenas no país. Os tapuias designavam o grupo nãotupi e eram encontrados facilmente no sertão do Maranhão, a exemplo dos timbiras.

Os sertões maranhenses, ao longo dos séculos XVI e XVII, sofreram forte pressão decorrente do desbravamento, promovido pela Coroa Portuguesa, e do pulsar das frentes de povoamento, ambos objetivando assegurar definitivamente a posse do território e, ainda, alargar áreas produtivas, abrir vias de comunicação para fins mercantis, aldear e pacificar os índios, garantir navegação segura nos rios e explorar riquezas desconhecidas, entre outros. Porém, as agruras físicas impostas pela paisagem e pelo contato com os indígenas frearam, por longo período, as investidas nessa região.

Socorro Cabral (1992) faz distinção entre as frentes de colonização do sul maranhense: a litorânea, que seguiu padrão de devassamento territorial se utilizando dos rios mais navegáveis (Itapecuru, Mearim, Pindaré e Grajáu), sob promoção do Estado, que chegou apenas a Caxias, e a do interior, frente de expansão vinda de estados nordestinos como Pernambuco e Bahia, que ficou também conhecida como frente pastoril baiana, e chegou até os sertões de Pastos Bons, designação dada a um território pioneiro para novas investidas na área do chamado Sertão Maranhense.

Nesse processo, típico da conquista territorial brasileira, os indígenas ou os tapuias foram violentamente perseguidos e afugentados, dizimados no Nordeste e afugentados em direção ao Maranhão, desde as entradas e bandeiras praticadas pela Casa da Torre 
Imperatriz: de Vila à Cidade Comercial

dos Garcia d'Avila. ${ }^{2}$ A área do sertão de Pastos Bons vivenciou o avanço da frente colonizadora pastoril baiana, mesmo que ainda freada pela ação dos guerreiros povos timbiras. Daí provém chamar-se de baianos no interior do Maranhão aos sertanejos ou habitantes do campo.

Outras frentes exploratórias moldariam os sertões. Segundo Franklin (2005), a frente de ocupação goiana, com interesses mercantis junto ao Pará, e, ainda, a frente colonizadora paraense, que desde o século XVII vinha desbravando o rio Tocantins em direção à sua nascente, com propósito de estabelecer ligação comercial com Goiás.

A atuação das frentes, como não poderia deixar de ser, se fez por terra e pela abundante rede hidrográfica da região, sobretudo o rio Tocantins, o rio Manoel Alves Grande e o rio Araguaia, hoje limites oficias da parte sul do estado do Maranhão.

O Tocantins é marco da fundação de Imperatriz e, durante toda a história de interiorização da região, foi alvo de várias incursões, não só para estudar sua navegabilidade, mas, sobretudo, para estabelecer missões religiosas para aldear os indígenas, estabelecer áreas de pousio para exploração de drogas e minérios, estabelecer fortificações e até prisões militares, enfim, para ocupar, garantir e alargar a posse do território.

Importante caminho de desbravamento para alcançar terras do Cerrado e da pré-Amazônia, só foi conhecido no final do século XVI e início do XVII. Creditam-se, com amplo registro, ao francês La Blanjartier, aos bandeirantes paulistas, a Daniel de La Touche (fundador de São Luís) e ao padre jesuíta Antônio Vieira as primeiras incursões no Tocantins em direção à nascente, as quais foram lenta e gradativamente vencendo os obstáculos à navegabilidade, como as corredeiras e cachoeiras de Tauiri e Itaboca (hoje represa de Tucuruí), e estabelecendo povoados (FRANKLIN, 2005).

A descoberta do ouro em Goiás e Mato Grosso estimulou a base de novos caminhos da Amazônia rumo àquelas paragens. Em torno de 1730, a navegação pelo rio Tocantins foi proibida por ordem régia, com o objetivo de impedir o contrabando do produto das recém-descobertas minas de ouro de Goiás pelos rios e estradas desertas dos sertões. Por mais de sessenta anos, essa medida, na teoria, impediu inúmeras missões exploratórias.

Contudo, cartas e documentos históricos registram os rumores do aclamado rio e designam ordens de levantamento de seu potencial, como apresentado no trecho a seguir:

Seguirá o rio dos Tocantins até entrar no grande de Araguaia, que navegará, examinando sempre com o maior cuidado aquellas notícias, que ha tantos annos nos prometem e assegurarão tão precizos haveres; e no cazo que tenha a fortuna de encontra-los, despedirá uma canoa das da sua conserva à toda a diligencia, informando-me cabalmente de tudo, com todas as circunstancias necessarias...[...] Continuando a sua navegação, informando-se cuidadoza e advetidamente dos tapuias do rio, de que nas margens d'elle ha alguma povoação de gente branca, fará todas as diligencias por examina-la; e achando ultimamente que é de naturaes (que serão sem duvida das minas de São-Paulo, ou da colonia do Sacramento novamente incorporada no nosso dominio) procurará logo avistar-se com o governador a quem dará individuaes noticias da sua viagem. (SANCHES, 2003. Regimento pelo qual o Governador Bernardo Berredo (do Maranhão) mandou descobrir o Rio Tocantins em 1719) 
Nogueira, C. R.

Em Carta Régia de 1798 foi determinado ao então governo do estado que promovesse os meios de navegação do Tocantins e do Araguaia para se alcançarem interesses comerciais entre as províncias do Pará, Goiás e Maranhão. Concediam-se, ainda, benefícios para os que se instalassem às margens dos rios, como declarado em outra Carta Régia, de 1806, onde se asseguravam "inteira isenção de dízimos por dez anos a quem for e estabelecer-se ao longo das margens dos mencionados rios, e ainda três léguas na distância dela" (SANCHES, op. cit., p.153).

O Maranhão cumpriu parcamente as determinações de colonizar as margens do rio Tocantins. Desbravadores tomaram conhecimento de sua localização em 1809, motivados pela procura de terras com melhores pastos, e, embrenhando-se pelo sertão, percorreram o rio Manoel Alves Grande e, finalmente, o Tocantins. Em 1810 formou-se o arraial de São Pedro de Alcântara, que viria a ser a atual Carolina, cidade sul-maranhense que por mais de um século seria mais importante do que Imperatriz.

Mais adiantados no processo de desbravamento do território, os estados vizinhos, Pará e Goiás, investiam nas incursões fluviais, não sem conflitos entre si: uma das incursões paraenses, em 1849-51, destinava-se ao estabelecimento de limites entre as províncias do Pará e Maranhão, a partir da fundação de uma colônia acima da confluência com o Araguaia, onde devesse limitar com o Maranhão. O litígio acerca dos limites das províncias gerou a missão com o religioso baiano frei Manoel Procópio do Coração de Maria, responsável pela fundação de Santa Teresa do Tocantins (destacada na figura 1).

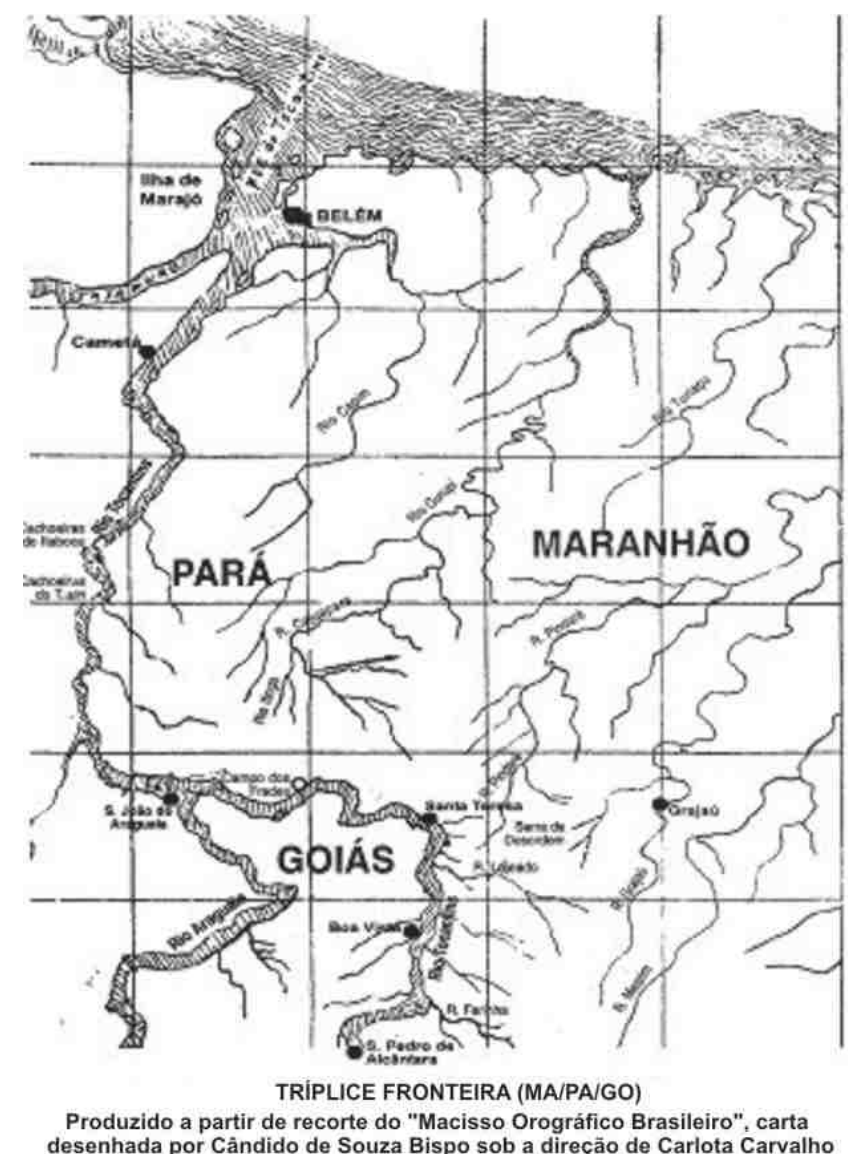

Figura 1 - Tríplice fronteira - estados do Maranhão, Goiás e Pará. Fonte: Franklin (2005). 
Imperatriz: de Vila à Cidade Comercial

\section{Surtos de Imperatriz como Centro Comercial Extrativista - de Vila à Cidade}

As bases para a fundação de Imperatriz deram-se somente em 1849-50, quando se estabeleceu, por designação da província do Pará, a povoação de Santa Teresa do Tocantins (homenagem a Santa Teresa D'Ávila) como uma colônia e um presídio militar. Esta objetivava dar apoio à navegação fluvial e facilitar as comunicações comerciais com a província de Goiás. A povoação não tardou a extinguir-se, pois seus parcos habitantes foram logo assolados por graves enfermidades.

Em 1854-55, dada a imprecisão dos limites entre Maranhão e Pará, foi evidenciado que a povoação de Santa Teresa do Tocantins, fundada por Frei Manoel, pertencia ao Maranhão, cujo governo à época pensava também em providenciar uma vila nas imediações da fronteira com o Pará. Em agosto de 1856, por meio de uma lei provincial, era constituída a "Vila Nova da Imperatriz", pelo governo maranhense, em homenagem à Imperatriz Teresa Cristina, mulher do Imperador Dom Pedro II, a quem os moradores rogavam suas demandas.

Devido a um desacerto político-administrativo, a Nova Vila da Imperatriz não era a da localização de Santa Teresa do Tocantins; parecia designar a povoação de Porto Fran$\mathrm{Co}$, um incipiente povoado maranhense fronteiriço a Boa Vista. Em meio a contestações e acirrada batalha entre as duas povoações, em dezembro de 1862, a sede do município de Porto Franco é estabelecida no povoado de Santa Teresa da Imperatriz e, por lei provincial, a Vila Nova da Imperatriz passa a se chamar somente Imperatriz.

Quanto ao surgimento de Imperatriz, alguns autores divergem dos fatos descritos e restringem-se a dizer que a vila foi fundada pela lei provincial de 1856, "à margem direita do Tocantins, em terreno que o governo [maranhense] julgasse mais conveniente para sua sede"(MARQUES, apud COUTINHO, 1994, p. 68).

Nas décadas seguintes, e até o fim do século XIX, a vila de Imperatriz, ou só Imperatriz, firma-se como território divisor entre Maranhão, Pará e Goiás, polo de criação de gado e porto fluvial para navegantes do rio Tocantins (FRANKLIN, 2005) e distribuidor de produtos e derivados de gado vindos de Belém. No entanto, Carolina, já como cidade em 1859, demonstrava mais vigor em sua ligação com centros comerciais do Pará e Goiás. A Vila de Imperatriz, quanto ao seu aspecto, não passava de uma rua com casas em parte cobertas de telhas, e em outras tantas de palha, edificadas ao longo do rio, terminando em uma praça ou largo, num quadrilátero em que foi construída a igreja-matriz (IBGE, 1957). De acordo com o historiador Mílson Coutinho, na época de sua formação poderiam se contabilizar "546 almas na Vila e em todo o município somaria de 18 a 29 mil habitantes [...] quarenta anos decorridos e a Vila ainda guardava o aspecto sombrio dos povoados interioranos, sem o menor sinal de progresso, educação, comunicações, etc." (COUTINHO, 1994, p.73).

O primeiro censo oficial do Brasil em 1872 designa ao município de Imperatriz, 9.732 habitantes. A imprecisão nos dados apresentados, fato comum à época, revela-se nas décadas seguintes, quando se registram 4.126 habitantes e 7.879 habitantes para os Censos de 1890 e 1900, respectivamente, números muito menores do que os apresentados por Coutinho para todo o município.

Ainda segundo Coutinho (1994, p.70-71), no período de 1856 e 1896 a Vila de Imperatriz "não apresentou, praticamente, qualquer surto de desenvolvimento digno desse nome". 
Nogueira, C. R.

Contudo, a ampla disponibilidade de terras devolutas - num município com uma área de 50 mil quilômetros quadrados - atraiu mais camponeses e criadores de gado para os recursos abundantes das "matas gerais", já existindo muitas fazendas e inúmeras cabeças de gado.

A fraca ou frouxa ocupação do sertão se apresentou, após reconhecimento pelas "bandeiras", baseada em duas atividades: a pecuária extensiva, dependente da demanda da marcha litorânea, e a agricultura de subsistência sobre queimada, completada pelo extrativismo (BITOUN, 1980). Os ciclos da castanha e da borracha também estão na lista das atividades econômicas que refletiram na vila de Imperatriz.

\section{A fundação da vila - posição estratégica no ciclo do gado}

A região de Goiás, cessada a corrida às minas de ouro responsável pela ocupação no Alto Tocantins, passara a repulsar a população, dado o declínio de sua atividade econômica. A região do Tocantins é afetada com esse movimento e nela passa a predominar a economia extrativista e pastoril. Há um crescimento do número de fazendas, atraindo criadores para o sertão dos Pastos Bons. O comércio do sul maranhense era feito por meio dos núcleos, como Riachão, Grajaú, Carolina e Pastos Bons, Porto Imperial, em Goiás, e São João do Araguaia, sob o controle do Pará.

A abundância de terras devolutas na região e a própria natureza da atividade pastoril que demandava vastas áreas, sob o estímulo do abastecimento das demandas do litoral, como Belém incentivou a ocupação de terras. Some-se a essas atrações o interesse em minar a resistência dos índios timbiras. Motivado por essas razões, o Pará passou a financiar rotas de comercialização - com a abertura de estradas - até o sul do Maranhão.

A abertura de estradas era essencial para complementar a navegação fluvial. Em toda essa região, os colonizadores dedicavam-se fundamentalmente à criação de gado, com mais valor para o couro do que para a carne. O couro era matéria-prima dos diversos produtos da vida sertaneja, e a carne era comercializada no Piauí e em Belém, em forma de charque, dada a falta de estradas adequadas à condução do gado e ao seu consumo como carne verde (FRANKLIN, 2008).

No início da segunda metade do século XIX, essa atividade recebeu maior incentivo por uma crise de abastecimento que se abateu sobre Belém, a qual levou o governador do Pará a propor aos criadores do sul do Maranhão medidas como a garantia de seu mercado e a abertura de estrada a partir da povoação de Santa Teresa. Apesar de tais incentivos, o transporte ainda era fator limitante.

Por outro lado, o governo do Maranhão, interessado em importar o gado para sua capital, projetou uma estrada em 1864, que é construída dois anos depois. O trajeto era em parte feito pela estrada e em parte por vapores da Companhia Fluvial pelo rio Tocantins. Essa construção resolveria dois problemas: a "definitiva" ligação do litoral com a região do Tocantins e o complicado abastecimento de São Luís, uma vez que regiões vizinhas não davam conta da demanda (ibidem).

Apesar da intenção, a estrada não favoreceu o desenvolvimento da região do Tocantins. Fatores como a falta de conservação, a força das matas e os perigos representados pelos indígenas que habitavam esse território contribuíram para o seu abandono e fizeram com que a região retornasse à condição de antes, fraca e esparsamente ocupada e com alto grau de isolamento. 
Quanto aos aspectos sociais do ciclo do gado, a atividade não dependia de mão de obra escrava, e os trabalhadores e agregados com a lida do gado (criadores e vaqueiros) tinham possibilidade de ascensão a fazendeiros. A atividade paralela à lida com o gado era a agricultura praticada apenas para subsistência (arroz, milho, feijão, cana-de-açúcar e mandioca), dada a própria dificuldade de exportar excedentes. A comercialização ficava por conta dos "couros secos, gados vacum e cavalar, óleo de copaíba de que muito e muito abundam as ubérrimas matas que circundam esta pitoresca vila [...] As matas, ricas de madeira para todo e qualquer uso, subministram saborosos frutos"(MARQUES, 1970, apud FRANKLIN, 2008, p.38).

Até a última década do século XIX, a economia da Vila estava baseada na criação de gado. Havia uma situação de forte potencial de desenvolvimento, dada a sempre propagada localização da Vila de Imperatriz, a existência de grandes fazendas de criação de boi - na Vila podia-se contabilizar 40 mil cabeças de gado - (COUTINHO, 1994) e forte demanda dos mercados consumidores (Belém e São Luís). No entanto, a reconhecida dificuldade de transporte (tempo longo e inadequação do meio físico) e a reduzida oferta de áreas de pousio para o gado que viajava a pé até as capitais (com o consequente emagrecimento e perda de reses) resultavam na limitação desse potencial e numa existência bem acanhada e até inteiramente esquecida.

\section{Os surtos do caucho e da castanha - Imperatriz elevada à cidade}

Somente em fins do século XIX amplia-se a base econômica local: valoriza-se a floresta e a extração vegetal, atividade chave na Amazônia e que remonta aos tempos coloniais e volta e meia retorna à cena. Ao lado da borracha, o mais eminente dos produtos extrativos foi a castanha. Imperatriz se consolidou como porto e centro comercial e fiscal da súbita expansão extrativista.

O ciclo da borracha tinha como fonte inúmeras espécies de árvores que produziam o látex. ${ }^{3}$ O boom econômico da borracha, com fortíssimo uso industrial do látex da seringueira, influenciou toda a região, inclusive a região do Tocantins, onde também se descobriu e explorou o látex do caucho, de qualidade inferior. A borracha transformou-se no segundo maior produto de exportação do Brasil (depois do café), calculando-se para a Amazônia um crescimento da população de 250 mil a 500 mil habitantes no período entre 1872 e 1900 (auge da produção).

A Amazônia recebeu mais de 260 mil imigrantes, especialmente nordestinos que, fugidos dos problemas estruturais do Nordeste e em direção à Amazônia, passaram pelos sertões maranhenses. A Vila de Imperatriz conheceu uma mudança relativa de rumo, como "boca de sertão", quando a descoberta do caucho valorizou a floresta e promoveu a integração do médio Tocantins no rol dos produtores do rico ciclo da borracha.

No início do século XX a Vila viveu um período de auge comercial pela elevada movimentação de seu porto e a arrecadação de impostos. Tornou-se polo receptor de ondas de imigrantes nordestinos (Bahia, Piauí, Ceará, Paraíba e Pernambuco) e do próprio estado do Maranhão, todos em busca do "Eldorado do Itacaiúna", localidade que mais tarde viria a ser Marabá, onde foi encontrado o caucho.

A Vila funcionou como abastecedora de alimentos para Itacaiúna e posteriormente como seu principal porto, levando diariamente a riqueza dos caucheiros (trabalhadores extrativistas do látex do caucho) em direção a Belém. 
Nogueira, C. R.

Também nessa localidade se processava a extração da castanha, nesse momento em segundo plano. A exploração da castanha em bases comerciais teria começado em 1800, quando era procurada como gulodice, e como os primeiros embarques para o exterior se fizeram pelo Maranhão, ela foi conhecida de início como "castanha-do-maranhão", e só mais tarde se generalizou como castanha-do-pará (SANTOS, 1980).

Na obra História econômica da Amazônia (ibidem), a castanha, antiga conhecida dos maranhenses, era explorada de forma limitada para fins de comercialização interna - alimentação de animais domésticos. "A consolidação de uma frente castanheira a montante do rio Tocantins, na qual Marabá se realçaria como a mais importante unidade produtora da Amazônia, não ocorreu senão após a grande queda da borracha"(SANTOS, 1980, p.183).

Os ciclos econômicos derivados de produtos extrativistas demandaram muita mão de obra, e a Vila exerceu papel de catalisadora e distribuidora desse componente da produção. Muitos imperatrizenses eram donos de castanhais na região e exploravam impetuosamente a força de trabalho masculina à época. A colheita das castanhas requeria certa bravura dos trabalhadores ao se embrenharem em matas fechadas e em clima bem insalubre, com risco de malária e, ainda, de ataques indígenas.

As tentativas de ligação de Belém ao médio e baixo Tocantins eram antigas, e novamente, antes dos maranhenses, os paraenses investiram no difícil plano de construção da ferrovia Tocantins-Araguaia, com o objetivo de superar as corredeiras e cachoeiras daquela parte do Tocantins. Iniciada para dar conta do secular isolamento, e mais especificamente da produção do caucho explorado na região, a Companhia de Estradas de Ferro do Norte do Brasil, em 1908, inaugura apenas 43 quilômetros de ferrovia ao longo do Tocantins, e com muita dificuldade, em 1916, consegue atingir o quilômetro 82. A Companhia sofre com problemas financeiros; passa a se chamar Companhia Estrada de Ferro do Tocantins, e logo depois é desativada. Como resultado, o projeto comandado posteriormente pelo governo federal se arrasta sem êxito, até a completa retirada dos trilhos em 1966 (FRANKLIN, 2008).

Em menos de vinte anos, a euforia do ciclo do caucho desapareceu. Na primeira década do século XX já era sentida a violenta queda da produção da borracha em toda a Amazônia, pela concorrência da produção asiática. A colheita e a comercialização da castanha começaram a perder importância na década de 1930, e logo depois deixaram de ser rentáveis. O impacto na Vila foi bastante sentido, deixando-a apática e sem vestígios dos equipamentos urbanos de tal período de "crescimento" econômico.

O período de declínio do ciclo da castanha e do caucho refletiu-se num aumento da produção de produtos agrícolas (arroz, milho, algodão), com uma maior dedicação às atividades agrícolas. No entanto, em recenseamento realizado em 1923, registrado em livro paroquial, "foi escrupulosamente contado o pessoal desta Vila e verificou-se ser composta de 823 pessoas" (LIVRO DA PARÓQUIA DE IMPERATRIZ, apud FRANKLIN, 2005, p.73).

Graças ao fraco surto extrativista, ainda assim, em 1924 a Vila é elevada à condição de cidade. Em meio às mudanças promovidas pelas atividades extrativistas, vai lentamente se modificando, apesar de ainda se encontrar numa situação de isolamento, sofrendo com a ausência de vias de comunicação dentro do próprio estado e com outras regiões. 
O problema de falta de comunicação afeta toda a região. A vizinha Carolina não difere da situação de isolamento, mas a construção de algumas estradas ainda no Império, a fim de facilitar o escoamento de gado sertanejo para o litoral, confere-Ihe uma posição mais privilegiada do que a de Imperatriz. O maior número de estabelecimentos comerciais e pessoal ocupado no comércio na década de 1940 e o fornecimento de energia elétricapuderam, à época, afirmar a superioridade não só de Carolina, mas de outras cidades do sertão sobre Imperatriz (Tabela 2). Ainda, Carolina é palco de acontecimentos políticos de âmbito nacional, como a visita da Coluna Prestes em 1925, dando-lhe prestígio cultural, além de concentrar todo o movimento de transporte com demanda crescente de passageiros e de carga do médio Tocantins e sul do Maranhão (transporte aéreo com seis empresas em funcionamento).

Tabela 2 - Pessoal ocupado no comércio em municípios selecionados do sul maranhense, 1940.

\begin{tabular}{lccc}
\hline Município & $\begin{array}{c}\text { Estabelecimentos } \\
\text { recenseados }\end{array}$ & $\begin{array}{c}\text { Pessoal ocupado } \\
\text { total }\end{array}$ & $\begin{array}{c}\text { Viajantes, agentes } \\
\text { compradores, etc }\end{array}$ \\
Carolina & 47 & 107 & 23 \\
Grajaú & 27 & 62 & 11 \\
Pastos Bons & 19 & 57 & 12 \\
Imperatriz & 18 & 40 & 5 \\
\hline
\end{tabular}

Fonte: IBGE (1940)

Na verdade, a melhor situação de Carolina deve-se à sua maior articulação com São Luís num momento em que eram mais importantes as relações com o litoral. Logo essa situação se modificaria, sob influência das transformações em curso no Brasil.

\section{Um breve surto de extrativismo mineral}

Se até então a Vila de Imperatriz era comandada por suas articulações, sobretudo com Belém, e também com São Luís, a partir de meados do século XX as influências sobre a cidade e sua área de entorno passam a vir do sul, ou melhor, das cidades do Rio de Janeiro e de São Paulo, onde convergiram as grandes transformações que marcaram o Brasil a partir de então.

Liberados os escravos e proclamada a República, gerada riqueza com o café, sucedem-se significativas mudanças no país. Sob tensões e conflitos, tenta-se fortalecer o Estado, iniciando um processo de industrialização e consolidando o controle do território.

Em finais da década de 1930, um clima de instabilidade relacionada à revolução de 1930 até a consolidação do Estado Novo e um discurso político de conquista do oeste apoiada na ideologia nacionalista sem uma prática orientadora desse movimento estimularam a migração, especialmente para a região Tocantina.

Ademais, entre a década de 1930 e 1940, a "febre" de garimpos de quartzo ou cristalderocha e de diamantes, ou ondas de migrantes novamente à busca de enriquecimento rápido ao longo dos rios da região Tocantina, reativaram muitas áreas de mineração. 
Nogueira, C. R.

A demanda do quartzo está ligada à indústria bélica e à necessidade desse mineral na fabricação de componentes eletrônicos, e esse material teve seu preço elevado no mercado externo, dado o período de guerra mundial.

Especificamente no município de Imperatriz localizou-se o garimpo do Clementino (de menor porte, mas com descoberta de diamante), e por toda a região e seus inúmeros garimpos (especialmente em Marabá) havia a necessidade de abastecimento de gêneros alimentícios, o que agitou o porto da cidade de Imperatriz, sem, no entanto, fixar população na cidade.

As estatísticas acusam para o município de Imperatriz uma população total de 9.331 habitantes em 1920, dos quais em torno de mil vivendo na cidade (vide tabela 3 da população urbana para o período de 1920 a 1970). De fato, a atividade econômica do município ainda era a mesma dos tempos da fundação, ou seja, agricultura e pecuária (COUTINHO, 1980).

A partir da década de 1940, a região Tocantina, pela reserva de riqueza natural e florestal, torna-se receptáculo de migração de camponeses sem terra do Nordeste. As causas já são conhecidas: a concentração de terras, o minifúndio se mostra incapaz de sustentar por longo tempo as famílias numerosas e a seca que assola o Nordeste de tempos em tempos (aproximadamente de trinta em trinta anos). Segundo Bitoun (1980), trata-se de um movimento espontâneo de agricultores de região semiárida para as terras livres e úmidas mais próximas, reforçado pelo refluxo daqueles que haviam partido para a Amazônia e tiveram seu destino ligado ao da borracha. Mais uma vez, a posição estratégica no contato com a floresta atrai populações.

Os migrantes que começam a chegar no final dos anos 1940 buscam atividade de agricultura típica de subsistência, uma vez que o sentimento de chegada à "terra prometida" é relativamente sentida pela presença de chuvas regulares e pela abundância de terras sem dono. A cidade é apenas um ponto de apoio à conquista do espaço florestal, segundo Bitoun (1980). O que justificaria em parte o descaso com o núcleo urbano que permanece com população em torno de mil habitantes por mais de trinta anos, até os anos 1950.

Tabela 3 - População urbana da cidade de Imperatriz.

\begin{tabular}{c|cccccccc}
\hline 1920 & 1940 & 1950 & 1960 & 1970 & 1980 & 1991 & 2000 & 2010 \\
\hline $\mathbf{8 2 3}$ & 1.178 & 1.152 & 8.986 & 37.698 & 111.619 & 210.051 & 218.673 & 234.547 \\
\hline
\end{tabular}

Fonte: IBGE (1920 - 2010).

Contudo, a tentativa de alcançar o sonho de se libertar da opressão dos latifúndios é frustrada mais uma vez, pois o boi e o capim expulsam novamente os "agricultores e o arroz", fato que se encontra na memória dos pioneiros da região de Imperatriz, quando foi rompido seu isolamento pela construção da rodovia Belém-Brasília e se dá início a um verdadeiro "ataque à terra" (BITOUN, 1980).

Os projetos políticos governamentais para a região seguindo visões integracionistase desenvolvimentistas pautaram-se na construção de eixos rodoviários e com fluxos financeiros externos à região. Fato é que a rodovia cortou o sertão brasileiro, interligando os 
Imperatriz: de Vila à Cidade Comercial

centros econômicos do sul à parte central e estagnada do país, promovendo especificamente a região Tocantina como o portal da Amazônia, acelerando o fluxo de migrantes pobres do Nordeste, incentivando projetos pecuaristas e trazendo capital especulativo do Sul com patrocínio do estado.

\section{A Rodovia e o Surto Demográfico e Econômico de Imperatriz}

O processo de industrialização, a introdução da indústria automobilística associada ao Plano de Metas de Juscelino Kubitschek com o famoso slogan de "50 anos de desenvolvimento em 5 anos de realizações", priorizando energia, transporte e indústria de base, e o projeto de transferência da capital política do país para o Planalto Central pintam o cenário no qual desponta a construção da "rodovia de integração nacional", a Belém-Brasília.

A década de 1950 foi sem dúvida um marco para o Brasil e para as cidades amazônicas, entre elas Imperatriz. Além do marco da construção da rodovia já citada, que abre caminhos para novos mercados, localmente a década marca a chegada de reincidentes ondas de migrantes nordestinos e maranhenses, seguidos de madeireiros e pecuaristas de Minas Gerais e Goiás.

\section{"Boom" migratório e início da fronteira agropecuária}

A construção da rodovia Belém-Brasília, iniciada em fins de 1957, priorizou um traçado bem próximo à linha de divisão das águas do Tocantins e do Araguaia, cruzando o rio Tocantins em Estreito, seguindo terrenos uniformes, passando por Imperatriz e seguindo até Belém. De todos os portos fluviais do Tocantins, os únicos privilegiados pelo traçado rodoviário foram então Porto Franco e Imperatriz, em detrimento de cidades bem estabelecidas, como Porto Nacional (GO) e Carolina (MA) (VALVERDE e DIAS, 1967).

Valverde e Dias (1967) fazem um estudo de geografia regional pormenorizado de toda a área afetada pelo traçado da estrada e uma análise comparativa entre cidades servidas direta e indiretamente pela BR-14. O trecho norte da secção central da rodovia é constituído porAraguaína, Carolina, Estreito, Porto Franco, Tocantinópolis, Imperatriz e Açailândia, onde efetivamente

Imperatriz está situada no contato entre cerradões e cerrados, que ficam para o sul, e as matas, que se expandem para o norte. Os cerradões são entremeados de babaçuais. A fisionomia desta formação parece estar mais próxima da original que a dos babaçuais homogêneos do norte do Maranhão, cujo caráter secundário é manifesto. (ibidem)

E as terras florestais ao norte, ainda dentro da hileia, têm feições distintas: até 38 quilômetros ao norte de Imperatriz predomina a vegetação natural de mata, alterando-se com pastos plantados, caracterizando-se por grandes propriedades, com invernadas e babaçuais, e uso expressivo da criação de gado.

Quanto à comparação entre as cidades servidas diretamente, realizada em fins dos anos 1960, é visto que Imperatriz participou historicamente de um importante eixo 
Nogueira, C. R.

econômico comandado por Belém desde o século passado, com uma economia muito mais agrícola do que pastoril, como Porto Franco. Ambas tiveram rapidamente meios mais rentáveis de escoamento de sua produção, facilitando as transações comerciais intensificadas com a BR-14, que provocou colapso da navegação fluvial em Porto Franco e Imperatriz, uma vez que, apesar de o frete rodoviário ser mais caro, ainda é mais vantajoso que o fluvial.

A cidade de Tocantinópolis, vizinha a Porto Franco, na margem esquerda do rio Tocantins (em Goiás), usufruiu da agilidade do transporte e conseguiu dinamizar e diversificar a economia inicialmente baseada no extrativismo. Já a cidade de Araguaína, sem tradição econômica ou de porto fluvial como Imperatriz, cresceu desordenadamente, sem plano preconcebido, mas viria a rivalizar com esta.

As cidades não servidas diretamente pela construção da BR-14, como Carolina e Porto Nacional, foram colocadas em situação de esquecimento do porvir do desenvolvimento. Carolina que por muito tempo se sobressaiu como cidade mais importante do sul do estado e como capital regional, foi definitivamente comprometida nas ligações fluviais com Belém, e não houve a abertura de frente pioneira depois que a rodovia foi posta em circulação, pois não existiam mais terras devolutas para a ocupação por novos posseiros, ao contrário do que aconteceu em Imperatriz.

A cidade de Imperatriz foi escolhida como um dos pontos estratégicos das operações de construção da rodovia, sob o comando da RODOBRAS (Comissão Executiva da Rodovia Belém-Brasília), subordinada à SPVEA (Superintendência do Plano de Valorização Econômica da Amazônia). Ao sul da cidade, nas savanas, a técnica de aerolevantamento permitia rápido avanço da construção. Contrariamente, ao norte, a densa floresta vai impondo um progresso lento, demandando muitos trabalhadores ("lenhadores") na abertura de picadas. A cidade torna-se palco de um sem-número de trabalhos públicos relacionados à BR-14 (BITOUN, 1980).

Nesse período da construção da rodovia, a população do município de Imperatriz salta de 14.064 para 39.169 habitantes, 75\% destes dedicados à atividades agrícolas, o que confirma os dados da crescente produção agrícola do município. Na área urbana, salta de mil habitantes para mais de 8 mil, antes aglomerados em meia dúzias de ruas próximas ao rio Tocantins, demandando expansão para abrigar novos moradores, o que é feito de forma relativamente planejada, com ruas paralelas à rodovia até a margem do Tocantins.

No Censo Demográfico de 1960, pela primeira vez foi efetuada pesquisa direta dos movimentos migratórios para formular o tempo de residência no município, revelando 30.900 pessoas não naturais de Imperatriz, das quais 20 mil residiam a até dois anos no município (Tabela 4), indicando movimento muito recente de migrantes.

Tabela 4 - Pessoas não naturais do município de Imperatriz por tempo de residência - 1960.

\begin{tabular}{ccccccc}
\hline $\begin{array}{c}\text { menos } \\
\text { de } 1 \text { ano }\end{array}$ & $\begin{array}{c}1 \text { a } 2 \\
\text { anos }\end{array}$ & $\begin{array}{c}3 \\
\text { anos }\end{array}$ & $\begin{array}{c}4 \\
\text { anos }\end{array}$ & $\begin{array}{c}5 \\
\text { anos }\end{array}$ & $\begin{array}{c}6 \text { a } 10 \\
\text { anos }\end{array}$ & $\begin{array}{c}11 \text { ou } \\
\text { mais }\end{array}$ \\
\hline 9198 & 10805 & 3453 & 2288 & 1793 & 2358 & 970 \\
\hline Total de imigrantes 30.900 & & & & \\
\hline
\end{tabular}

Fonte: IBGE (1920-2010). 


\section{O "Boom" do arroz}

A construção da rodovia, contudo, já estava precedida por uma migração espontânea, sendo que a produção agrícola era pautada fortemente no arroz, principal produto agrícola comercializado no município - superando a tradicional de cana-de-açúcar, produzida nos engenhos das fazendas, muito comuns no então emancipado município de Montes Altos -, e na produção de mandioca e extração da amêndoa do babaçu (Tabela 5).

Tabela 5 - Produção agrícola de 1950 para o município de Imperatriz.

\begin{tabular}{|c|c|c|c|}
\hline \multicolumn{4}{|c|}{ Produção Agrícola - 1950} \\
\hline Produtos & Unidades & Volume & Valor $(\mathrm{Cr} \$)$ \\
\hline Arroz em casca & saco de $60 \mathrm{~kg}$ & 18.700 & 1.309 .000 \\
\hline Laranja & centro & 8.500 & 127.000 \\
\hline cana-de-açúcar & tonelada & 17.700 & 1.070 .000 \\
\hline Banana & cacho & 13.600 & 81.000 \\
\hline Feijão & saco de $60 \mathrm{~kg}$ & 1.230 & 356.000 \\
\hline Mandioca & tonelada & 86.070 & 915.000 \\
\hline Cebola & $\mathrm{kg}$ & 3.450 & 57.500 \\
\hline Milho & saco de $60 \mathrm{~kg}$ & 8.000 & 424.000 \\
\hline Fumo & $\mathrm{kg}$ & 17.850 & 83.000 \\
\hline Manga & centro & 39.990 & 899.850 \\
\hline Farinha de mandioca & kg & 180.500 & 361.000 \\
\hline Aguardente de cana & litro & 1.900 & 171.000 \\
\hline Rapadura & kg & 19.175 & 134.225 \\
\hline Arroz pilado & $\mathrm{kg}$ & 172.160 & 95.410 \\
\hline Amêndoa de babaçu & tonelada & 220 & 1.320 .000 \\
\hline
\end{tabular}

Fonte: Sanches, 2003.

Os nordestinos migrantes, na maioria maranhenses, cearenses e piauienses, plantavam arroz em áreas abertas sem cercas, em terras ainda desocupadas, na condição de posseiros, condição essa que vai, mais tarde, facilitar sua expulsão.

O crescimento da produção na década de 1950, contudo, passa a ter nova motivação e nova feição - trata-se agora da lavoura de arroz para preparo de pastagens, durante dois ou três anos, prenunciando a chegada da frente pastoril na região vinda sobretudo de Minais Gerais e Goiás.

Altera-se significativamente a economia da região. Em 1955, o município de Imperatriz emancipa o então distrito de Montes Altos, que detinha a maior parte da produção agropecuária realizada em grandes propriedades. No Censo Agrícola do IBGE de 1960 é mostrada a diferença de área ocupada pelos estabelecimentos rurais: Imperatriz, com 1.705 estabelecimentos recenseados em uma área total de 5.828 ha, enquanto Montes Altos apresenta 392 estabelecimentos em uma área total de 18.476 ha. O município 
Nogueira, C. R.

de Imperatriz detinha um maior número de "pequenas propriedades", possivelmente com mais alta produtividade efetivada pela crescente demanda dos migrantes por terra e trabalho.

O arroz cultivado em Imperatriz e arredores (Vale do Mearim e Pindaré), do tipo Catete, ou "do Maranhão", encontrou, à época, farto mercado nos grandes eixos urbanos do sul (especialmente MG) e despertou investimentos de máquinas de beneficiamento de arroz por políticos e comerciantes imperatrizenses. A forte produção de arroz em terras férteis do sul do estado, somada à nova logística de transporte, levou o Maranhão a tornar-se o segundo maior produtor de arroz do país.

Antes mesmo da inauguração da rodovia, a arrecadação municipal crescera enormemente. Em 1952 havia sido de 421 mil cruzeiros. Corridos três anos, encontrava-se em 772 mil cruzeiros, e no ano de 1958 passou a 1.262 milhão de cruzeiros (FRANKLIN, 2008). Esse crescimento econômico deve-se à produção agrícola e comercialização, principalmente do arroz, advindas da nova fronteira agrícola, conhecida como a "estrada do arroz" (Imperatriz-Grajaú). Imperatriz lidera a produção na região Tocantina com aproximadamente um terço desse volume, dividindo volume considerável com Carolina, Riachão e Amarante do Maranhão. Em 1960 a região produziu 18,949 milhões de quilos, destes, 6,5 milhões de quilos vindos de Imperatriz.

Apesar do crescimento do cultivo do arroz, este se fez de modo extensivo, utilizando técnicas rudimentares, o que de certa forma contribuiu para que a produção não conseguisse ainda maior expansão (SOUZA, 2005). Ademais, apesar dos avanços nas instalações industriais para beneficiamento do produto, este ainda era regulado pela variação do mercado local.

É, sem dúvida, a construção da rodovia redentora, a Belém-Brasília (BR-14), que dá início à integração da promissora, mas secularmente estagnada Imperatriz. Os Censos Industrial e Comercial (IBGE, 1950, 1960 e 1970) mostram uma mudança avassaladora a posteriori da abertura da rodovia Belém-Brasília, especialmente ligadaà indústria alimentícia. Se na década de 1950 havia apenas cinco estabelecimentos industriais desse ramo (e somente esses), com valor de produção de 970 mil cruzeiros e inexistência de comércio atacadista, na década de 1960 há nada menos que 22 indústrias de beneficiamento de arroz, e na década de 1970 dobra-se o número das indústrias de beneficiamento de arroz, algodão e de extração de óleo (do babaçu) juntas, em um universo de 180 indústrias no município.

\section{Surto demográfico-econômico de Imperatriz - a fronteira implantada}

A partir da década de 1960 há um crescimento sem igual da cidade de Imperatriz, devido à sua localização em relação aos eixos viários, atuando como foco urbano através do qual se integram as regiões Norte, Nordeste e Centro-Oeste. O Projeto de Desenvolvimento Integrado da Bacia Araguaia-Tocantins - o PRODIAT (Brasília, 1985) destaca os principais fatores que determinaram o crescimento da cidade e de sua área de influência:

a) a articulação de ações governamentais federais e estaduais na abertura de vias de penetração, que permitiram a maior acessibilidade de Imperatriz a Belém, São Luís 
e ao Centro-Oeste, como também o acesso a novas terras e a ocupação de terras devolutas nas zonas do rio Pindaré, do vale do rio Mearim e da pré-Amazônia maranhense;

b) a posição geográfica de Imperatriz como ponto intermediário entre dois polos regionais (Belém-Brasília/Goiânia);

c) a existência de grandes áreas de terras devolutas de boa qualidade para cultivos agrícolas.

A nova lógica de ocupação da Amazônia, vista como fronteira econômica, atrai capital volumoso do Centro-Sul, conduzida pelo próprio governo, que passa a viabilizar a ocupação de terras à frente da expansão pioneira, o que gerou "avanços", desconsiderando essa ocupação pioneira na região. De forma geral, houve o chamado "fechamento" das fronteiras agrárias, envolvendo as questões de colonização da Amazônia e a participação de grandes empresas deslocando a pequena produção agrícola (SILVA, 2001).

O conceito de fechamento de fronteira está ligado à não mais existência de "terras sem donos" que possam ser ocupadas por pequenos produtores de subsistência, como pode ter sido o caso da produção agrícola dos migrantes em torno de Imperatriz. O ciclo do arroz perde força na década de 1970 para dar vez às grandes fazendas de gado, que foram tomando terras através da conhecida grilagem, processo comum no país ligado às novas áreas de expansão agrária.

Cabe lembrar que a condição de posseiro da maior parte dos produtores da região de Imperatriz facilitou a tomada de terras pelo avanço de novos interesses para a região e pelo simples e ilícito processo de grilagem. Imperatriz então perde sua primazia em relação ao cultivo do arroz, em função do aumento do latifúndio e do crescente investimento em pecuária e na extração da madeira.

O asfaltamento da Belém-Brasília em 1974 significou uma nova etapa na expansão da fronteira agropecuária, abrindo caminho para um processo de interiorização da urbanização na Amazônia Oriental. Esse fenômeno é notado em cidades como Marabá, no sudeste do Pará, Araguaína, no norte do Tocantins, e Imperatriz no Maranhão, onde houve forte crescimento econômico e um voraz "ataque à terra" (BITOUN, 1980). Implanta-se a fronteira móvel com todos os seus requisitos - crescimento demográfico, da agropecuária, da exploração do ouro etc.

$\mathrm{Na}$ virada da década, a produção expressa a expulsão da fronteira - retorna o crescimento da produção do arroz para a formação de pastos e se inicia o desflorestamento com a exploração da madeira. Em 1978-79, a área cultivada de arroz era de 45.400 hectares, com produção em torno de 79 mil toneladas. No período de 1981-82, a área cultivada passa a 66 mil hectares, com uma produção em torno de 118 mil toneladas. Mas é a exploração da madeira que vai dar o tom da mudança, intimamente associada à expansão da pecuária.

Por meio da grilagem, expropriações e violência no campo para instalação de grandes propriedades, abriram-se áreas para a plantação de capim e criação de gado. Na cidade instalaram-se dezenas de serrarias de pequeno e médio porte, e posteriormente, as de grande porte. Se em um primeiro momento as madeiras foram transportadas em toras, em caminhões abertos, pela rodovia asfaltada, em um segundo momento começaram a ser beneficiadas pelas serrarias e depois pelas movelarias. No Censo Industrial do IBGE 
Nogueira, C. R.

de 1970 já se contabilizavam quatorze estabelecimentos desse tipo instalados na cidade de Imperatriz, além de mais de uma centena de outros estabelecimentos industriais.

A cidade abrigava uma população que, expulsa do campo, procura emprego na indústria crescente e nos grandes projetos de mineração. A população passava de 8.986 habitantes, na década de 1960, para aproximadamente 34 mil habitantes na década de 1970, com uma paisagem de comboios de caminhões de madeira e arroz trafegando pela rodovia a partir de Imperatriz, reforçando sua posição de entreposto comercial.

A atividade madeireira desenvolvida em Imperatriz foi essencialmente nômade; retirava-se madeira direto das propriedades sem a menor preocupação com replantio, fora o que era perdido pelas queimadas, geralmente por descaso. A escassez de madeira em menos de dez anos de atividade tornava-se evidente. Na cidade, a carência de estrutura energética dificultava o desempenho das indústrias do setor e da própria vida na cidade, apesar da implantação de central elétrica em 1971, a CEMAR (Central Elétrica do Maranhão), no intuito de atender à crescente demanda industrial.

Mais uma vez o desmembramento territorial, desta vez de Açailândia, em 1981, que fica com mais de metade do espaço de Imperatriz, carrega para si a condição de polo madeireiro, antes posição detida por Imperatriz. A indústria madeireira segue rumo às novas áreas de extração, de matéria-prima farta, pois na lógica do setor, a atividade ficaria inviável pelo alto custo do transporte e pelas crescentes exigências fiscais e ambientais na utilização dos recursos naturais.

A tendência foi migrar mais para o norte, dada a abundância de madeira encontrada na floresta pré-amazônica ao norte de Imperatriz e em direção ao Pará, e seguir para cidades com uma logística territorial mais consolidada, como poderia ser o caso de Açailândia. Uma das ferrovias da região, a Norte-Sul, idealizada pelo estado em 1980, opera num trecho curto entre Estreito e Açailândia, que se conecta ainda com a Estrada de Ferro dos Carajás (BECKER e STENNER, 2008). Tudo isso favoreceu a cidade de Açailândia como polo madeireiro mais dinâmico do que Imperatriz, apesar de esta manter melhor posição no quesito comércio e serviços em ampla área de influência: a Tocantina.

Segundo o REGIC (Regiões de Influência das Cidades), trabalho executado pelo IBGE desde 1966, a rede urbana pode ser observada em duas dinâmicas distintas: a de um sistema de localidades centrais que comanda sua hinterlândia e de um sistema de cidades articuladas em redes. A cidade de Imperatriz dá um salto na hierarquia urbana, de centro sub-regional (categoria A), no ano de 1966, para o nível de capital regional em 1978, permanecendo assim até o último REGIC, em 2007. Houve alteração não só na hierarquia, mas no alcance da atuação territorial. Situação similar ocorreu em Açailândia - que salta de patamares ainda inferiores - e Marabá e Santarém, no Pará, que também se posicionam como capital regional, o que ratifica ainda mais o vertiginoso crescimento dessas cidades após a construção e o asfaltamento da rodovia Belém-Brasília.

Na década de 1980, declina a extração da madeira e a produção do arroz, e nova corrida de ouro se processa no Brasil; nasce o garimpo de Serra Pelada no sul do Pará, a apenas 150 quilômetros de Marabá e 350 quilômetros de Imperatriz. Há uma intensa mobilização de desempregados de grandes projetos governamentais, como a hidrelétrica 
de Tucuruí e a Transamazônica, e expropriados do campo de toda parte do Brasil, especialmente do Nordeste, via Maranhão.

Toda região Tocantina é afetada pela própria lógica dos grandes projetos que ocorrem na Amazônia Oriental, com atuação de grandes corporações apoiadas pelo Estado nacional que exercem influência em gigantescos territórios. A construção das grandes rodovias de integração, usinas hidrelétricas e projetos minerais, a exemplo do Programa Grande Carajás (PGC), se configuram nessa nova lógica de organização do capital (financeiro mais internacionalizado) e seus reflexos territoriais.

A cidade de Imperatriz passa a ser, mais uma vez, ponto de apoio em termos de abastecimento de produtos à crescente demanda dos garimpos paraenses. Seus setores de transporte, máquinas e alimentos são favorecidos em função da dinâmica da atividade e sua valorização no mercado internacional. O garimpo de Serra Pelada é inundado por trabalhadores braçais sem terra e sem emprego estável, funcionando como válvula de escape à tensões sociais em um primeiro momento.

Os valores de produção para o ouro extraído de Serra Pelada são controversos; estima-se em quarenta toneladas o ouro acumulado em 1988, certamente não contabilizando o contrabando. Mas segundo o Departamento Nacional de Pesquisas Minerais, a DNPM, entre os principais compradores de ouro do estado do Pará está a Caixa Econômica Federal (em algum momento exclusiva compradora), com valores de 6,32 e 3,18 toneladas para os anos de 1986 e 1987, respectivamente, para um total de 16,186 toneladas para os dois anos com outras empresas compradoras (Tabela 6).

A tabela dos principais compradores de ouro, mesmo se referindo ao estado do Pará, mostra a queda no volume de produção, dadas as perigosas condições de trabalho e o alto nível de insalubridade no considerado "formigueiro humano" em que se transformou Serra Pelada. A cada acidente que envolvia centenas de trabalhadores, o governo era pressionado a cessar a garimpagem manual e entregá-la à exploração mecanizada via grandes empresas mineradoras e a companhia Vale do Rio Doce, estatal que detinha a licença e o monopólio da atividade.

Mesmo com todos os acidentes e a crescente dificuldade na produção, o sonho de rápido enriquecimento ainda vagava no imaginário coletivo, e o envolvimento de Imperatriz era tamanho, que se fez ligação aérea e rodoviária diária com o garimpo. Eram três empresas aéreas com passagens nos valores de 14.000 cruzeiros para um tempo de voo de cinquenta minutos e vários ônibus com valores em torno de 1.500 cruzeiros.

Segundo análise do GETAT (Grupo Executivo de Terras do Araguaia-Tocantins, iniciativa do Governo Federal em 1980), o setor urbano da economia na área-programa, que abrange centralmente Imperatriz e Açailândia, se beneficiou com a construção da hidroelétrica de Tucuruí e dos projetos do PGC, pois muitos dos trabalhadores dessas obras eram residentes de Imperatriz e de lá direcionavam capital para Serra Pelada, por exemplo. Ainda no PGC, outros projetos agregados previam a instalação de empresas de metalurgia, além de projetos agrícolas de exportação, como soja e monoculturas florestais, como de eucalipto no município de Imperatriz, que até então englobava Açailândia. 
Nogueira, C. R.

Tabela 6 - Principais companhias de ouro do estado do Pará - década de 1980.

\begin{tabular}{lcc}
\hline \multicolumn{1}{c}{ Compradores (+ de 10 Kg Au/mes) } & 1986 & 1987 \\
Caixa Econômica Federal & & \\
J.V. de Oliveira & $6.324 .963,39$ & $3.177 .787,35$ \\
Companhia Real de Minerais & $1.062 .062,55$ & - \\
Somar Metais Ltda & $591.350,80$ & - \\
Metalmil Ind. E Comércio Ltda & $432.657,60$ & $162.168,10$ \\
Purificação de Metais Carol Ltda & $401.324,53$ & $147.566,47$ \\
Marsan Metais Ltda & $277.892,33$ & $95.297,00$ \\
Purimil Metais Ltda & $271.024,50$ & $309.675,90$ \\
R.B. Mendonça Agropecuária e Mineração & $247.503,92$ & $135.213,00$ \\
Comercial Ourominas Ltda & $112.342,71$ & - \\
Gold Mine Metais Preciosos Ltda & - & $128.738,19$ \\
Reservas Metais Preciosos Ltda & - & $118.842,62$ \\
Diversos & - & $99.382,0$ \\
Total & $1.346 .208,49$ & $840.648,70$ \\
\hline
\end{tabular}

Fonte: DARFS-DNPM (s.d.)

O GETAT era também responsável pela regularização e reestruturação fundiária no município, que enfrentava uma brutal mudança nas relações produtiva e de trabalho no campo. Os latifúndios cresceram, até para cumprir as metas dos projetos para a região (a exemplo de amplas produções de celulose), e os conflitos de interesses entre madeireiros, agricultores e pecuaristas se acirravam, o que significa dizer que o município de Imperatriz recebeu mais e mais migrantes oriundos dessa problemática, entre outras.

Em termos econômicos, na década de 1980, a cidade se beneficiou com um volume substancial de rendimentos do trabalho e do capital provenientes de seu exterior e que foram aplicados na área em atividades agropecuárias, industriais e especialmente comerciais. Em termos demográficos, no período entre 1980 e 1990, Imperatriz recebeu 88.560 imigrantes, o que equivale a $32 \%$ do total da população. Constata-se, pelos dados do IBGE, que 13.520 dos imigrantes que se fixaram na cidade provinham do Pará, possivelmente pela desativação dos diversos garimpos de ouro, especialmente o de Serra Pelada (FRANKLIN, 2008).

A população do município de Imperatriz, pelo Censo de 1991, era de 276.502 habitantes, número que foi reduzido com a emancipação de Davinópolis, Ribamar Fiquene, São Francisco do Brejão, Cidelândia, Vila Nova dos Martírios e São Pedro da Água Branca. O território de Imperatriz passa a ter, no final da década de 1990, apenas $1.368 \mathrm{~km}^{2}$, o que indicou uma enorme perda de população rural, daí a redução de população municipal entre 1991 e 2000 (Tabela 7). No entanto, a densidade demográfica da cidade salta de 41,35 hab/ $\mathrm{km}^{2}$ em 1991 para 168,54 hab/km² em 2000, devido à redução territorial. 
Imperatriz: de Vila à Cidade Comercial

Tabela 7 - Evolução da população de Imperatriz.

\begin{tabular}{crrrrr}
\hline Ano & 1970 & 1980 & 1991 & 2000 & 2010 \\
Cidade de Imperatriz & 34.698 & 111.619 & 210.051 & 218.673 & 234.547 \\
& & & & & \\
Município de Imperatriz & 80.827 & 220.079 & 276.502 & 230.566 & 247.505 \\
\hline
\end{tabular}

Fonte: IBGE (1920-2010).

A partir dos anos 1980 e 1990, o avantajado comércio de mercadorias e a crescente prestação de serviços levaram Imperatriz à condição de polo sul-maranhense e pré-amazônico. Passa então a ser conhecida como Portal da Amazônia, Metrópole da Integração Nacional e Capital Econômica do Interior Maranhense.

\section{Aurora do Século XXI e Retorno à Relativa Estagnação}

Imperatriz chega em fins do século XX com 94,84\% de população concentrada na área urbana, consolidando a prevalência das atividades ligadas ao meio urbano. Aquela vila que se estabeleceu com atividades pastoris e agrícolas e por quase todo o século XX voltou-se também às atividades extrativas mineral e vegetal não estabeleceu um parque industrial significativo e duradouro.

A dizer, o projeto do Distrito Industrial de Imperatriz (1988)destinou mais de 100 hectares ao longo da BR-014 para indústrias de pequeno e médio porte, com infraestrutura básica para as necessidades industriais, mas foi abandonado. Ainda hoje é possível ver a área à beira da estrada sem nenhuma utilidade, a apenas quinze minutos da cidade.

Imperatriz faz jus à condição de polo comercial e de serviços especializados, especialmente na educação e na saúde. No último Censo, empregava $27 \%$ da PEA do município no setor terciário da economia, que representa mais de $74 \%$ do PIB, e a arrecadação com ICMs é crescente desde 1999, de valores de 21,4 milhões de reais a 59 milhões de reais em 2004.

Os investimentos nos setores de saúde e de educação são expressivos. A infraestrutura de saúde cresceu rapidamente no final da década de 1990; são mais de 25 hospitais concentrados na área urbana e pouco mais de uma centena de postos de saúde espaIhados por todo o município. A rede de saúde se verticalizou a tal ponto, que é possível encontrar clínicas de tratamentos super especializadas, como de musicoterapia de reabilitação, com sauna, massoterapia etc.

Tal crescimento decorre da própria posição de Imperatriz. Vale dizer que a região de Imperatriz é uma zona de intensa movimentação migratória, e o mesmo acontece com os vírus trazidos pelos viajantes, sem contar que está nas bordas da hileia amazônica, ou seja, com forte presença de malária. Tais condições, somadas às péssimas condições sanitárias da maioria da população, criam um quadro desolador para a população mais pobre.

Os serviços de educação têm ampliado a qualificação dos próprios servidores da saúde, com cursos superiores de Odontologia, Farmácia-Bioquímica e Enfermagem. Além de mais de duzentas escolas de nível médio, técnico, hoje existem campi da 
Nogueira, C. R.

Universidade Estadual e Federal do Maranhão e CEFET. Também se encontram faculdades particulares, a exemplo da FACIMP, que tem um prédio moderníssimo com total financiamento do BNDES. Esse leque de possibilidades no campo educacional potencializa a posição de Imperatriz como centro de capacitação.

A cidade chega no século XXI como referência regional nesses dois ramos de serviços e como polo varejista e atacadista de mercadorias. A produção agrícola, outrora rica, fica em situação de déficit para o abastecimento da população. Muitos dos gêneros de grande consumo poderiam ser produzidos na própria região, e são importados, encarecendo o seu valor e dando continuidade à presença de atravessadores, dificultando assim o acesso de alimentos à população.

A possibilidade de investimentos tecnológicos e de subsídios à produção agrícola e extrativa com valor agregado local poderia ser um meio de desenvolvimento, com implantação de agroindústrias, aproveitando o potencial de entreposto comercial. Ao contrário, os projetos de instituições financeiras e governamentais ainda priorizam grandes investidores e empregam recursos para a extração de riqueza sem deixar nenhum legado marcante para as cidades e sua população. Fazem exceções algumas ONGs, instituições como o SEBRAE e ações socialmente corretas de grandes bancos que investem em pequenos projetos de "arranjos produtivos locais" visando semear um desenvolvimento sustentável a médio prazo entre comunidades rurais desconectadas.

O dinamismo vivido pela cidade na segunda metade do século $X X$ cessa na virada do século XXI. Se por um lado aquele dinamismo culminou numa cidade tentacular, exercendo um contínuo alongamento desses tentáculos, muitas delas mais no sentido de veias abertas de circulação de mercadorias, por outro a diversificação de atividades novas a cada ciclo econômico, de fato, não a transformou numa cidade dinâmica, e sim em mera espectadora de estímulos externas. A incapacidade de promover a industrialização de seus produtos foi fatal, impedindo a introdução de trabalho efetivamente novo, capaz de dinamizá-la e à sua região.

\section{Agradecimento}

Pesquisa desenvolvida junto ao Projeto Universal "Amazônia: por uma Fronteira Urbanizada" do Conselho Nacional de Desenvolvimento Científico e Tecnológico - CNPq coordenado pela Prof. Dra. Bertha Koiffmann Becker no Laboratório de Gestão do Território - LAGET - da Universidade Federal do Rio de Janeiro.

\section{Referências Bibliográficas}

ALMEIDA, C. M. A Carolina ou a definitiva fixação de limites entre as Províncias de Maranhão e de Goiás. Imperatriz: Academia Imperatrizense de Letras, [1852] 2007.

BANDEIRA, L. A. M. O feudo - A Casa da Torre de Garcia D'Avila: da conquista dos sertões à independência do Brasil. Rio de Janeiro: Editora Civilização, 2000.

BECKER, B. K. Amazônia. Serie Princípios. São Paulo: Editora Ática, 1998. 
Imperatriz: de Vila à Cidade Comercial

; EGLER, C. A. G. Brasil: uma nova potência regional na economia - Mundo. Rio de Janeiro: Bertrand Brasil, 1993.

; STENNER, C. Um futuro para a Amazônia. São Paulo: Oficina de Textos, 2008.

BITOUN, J. Ville et développement regional dans une région pionniaire au Brésil - Imperatriz, Maranhão. Sorbonne: Université de Paris I Panthéon, 1980.

BRASÍLIA, PRODIAT. Projeto de Desenvolvimento Integrado da Bacia do Araguaia-Tocantins. Plano de Desenvolvimento da Área-Programa de Imperatriz. 1985. 96p.

CABRAL, M. do S. C. Caminhos do gado conquista e ocupação do sul do Maranhão. São Luís: SIOGE, 1992.

COUTINHO, M. Imperatriz: subsídios para a história da cidade. São Luís: SIOGE, 1994.

DINO, S. Parsondas de Carvalho: um novo olhar sobre o Sertão. Imperatriz: Editora Ética, 2007.

FRANKLIN, A. Breve história de Imperatriz. Imperatriz: Editora Ética,2005.

.Apontamentos e Fontes para a história econômica de Imperatriz. Imperatriz: Editora Ética, 2008.

GAIOSO, R. J. de S. Compêndio histórico-político dos princípios da lavoura do Maranhão. Rio de Janeiro. Editora Livros do Mundo Inteiro, 1970. 537p.

GONÇALVES, C. W. P. Amazônia, Amazônias. São Paulo: Editora Contexto, 2001.

IBGE. Enciclopédia dos Municípios. Histórico de Imperatriz no Maranhão. 1957, p.195-8. . Censos Industrial e Comercial do Brasil. Rio de Janeiro: IBGE, 1950-1970. . Censos Demográficos do Brasil. Rio de Janeiro: IBGE, 1920-2010. . Censo Agropecuário. Rio de Janeiro: IBGE, 1960.

IPEA. Redes urbanas regionais: Norte, Nordeste e Centro-Oeste /Instituto de Pesquisa Econômica Aplicada, Coordenação Geral de Política Urbana, [e] Instituto Brasileiro de Geografia e Estatística, Departamento de Geografia, [e] Universidade Estadual de Campinas, Núcleo de Economia Social, Urbana e Regional. Brasília: IPEA, 2002.

LIMA, C. História do Maranhão. São Luís: Instituto Geia,1981.

MEIRELES, M. M. História do Maranhão. 1.ed. Rio de Janeiro: DASP, 1960. 
Nogueira, C. R.

; História do Maranhão. 4.ed., revisada. Imperatriz: Editora Ética, 2008.

MONTEIRO, J. M. Tupis, tapuias e historiadores:estudos de história indígena e do indigenismo. Tese apresentada para o Concurso de Livre Docência Área de Etnologia, Subárea História Indígena e do Indigenismo. Unicamp, São Paulo, 2001.

RIBEIRO, M. Â. C. A complexidade da rede urbana amazônica: três dimensões de análise. Rio de Janeiro. Tese de Doutorado, PPGG/UFRJ, 1998.

SANCHES, E. (org). Enciclopédia de Imperatriz. Imperatriz, Instituto Imperatriz, 2003.

SILVA, J. G. O que é questão agrária. São Paulo: Editora Brasiliense, 2001.

STUDART FILHO, C. Fundamentos geográficos e históricos do estado do Maranhão e Grão-Pará, com breve estudo sobre a origem e evolução das capitanias feudais do Norte e Meio Norte. Rio de Janeiro: Biblioteca do Exército, 1959. 359p.

SOUSA, J. de M. A cidade na região e a região na cidade: a dinâmica de Imperatriz (MA) e suas implicações na região Tocantina. Dissertação de Mestrado, UFG, 2005.

FUNDAÇÃO VALE. Um olhar sobre Imperatriz: diagnóstico socioeconômico. 2012. Disponível em: <www.fundacaovale.org/pt... fundacao-vale/.../livreto_Imperatriz.pdf>.

VALVERDE, O.;DIAS, C. V. Rodovia Belém-Brasília: estudo de geografia regional. Rio de Janeiro: IBGE, 1967.

Recebido em: 1/11/2012

Aceito em: 30/5/2013

\footnotetext{
1 O termo Tocantina refere-se usualmente às áreas próximas do rio Tocantins e é uma provável analogia à ferrovia defendida em início do século XIX para a região. O rio Tocantins segue o nome de uma tribo indígena da região, a tribo tocantin, que singnifica, em tupi, "bico/nariz de tucano", ave típica do local.

${ }^{2}$ A Casa da Torre de Garcia d'Ávila foi considerada o maior latifúndio do Brasil, localizado na Bahia. Sua história está registrada na conquista e no povoamento dos sertões do Nordeste do Brasil, participando da defesa da terra e da expulsão de piratas e invasores estrangeiros, assim como das lutas, havidas na Bahia, pela independência e constituição do Império do Brasil.

${ }^{3} \mathrm{O}$ caucho, nome vulgar da castilloa alei, é uma dessas árvores que produz látex de qualidade inferior ao famoso látex da heveabrasiliensis, mas de boa aceitação comercial. O caucho foi descoberto na passagem para o século XX na região do médio Tocantins, enquanto a hevea foi descoberta em torno de 1740 e tinha como habitat toda a região amazônica.
} 